Jean-Marc Wagner* and Adelheid Hu

\title{
Construction of difference and homogeneity: Teacher narratives about diversity in the Luxembourgish school system
}

https://doi.org/10.1515/eujal-2019-0047

Abstract: The school environment of the 21st century is shaped by rapidly changing social and societal conditions that teachers need to adapt to, increasing linguistic, cultural and ethnic diversity among other things. The development of attitudes to cope with these constant societal transformations is one of the main challenges of teacher professionalization today. In this chapter, we concentrate on the self-positioning and argumentation patterns of two Luxembourgish primary school teachers. We focus on the question how these teachers construct differences and homogeneity, what kind of categories and norms they rely on (e.g. performance, sociocultural background, and language) and in how far mechanisms of in- and exclusion become visible.

With its trilingual tradition and school system (mainly Luxembourgish, French and German), and at the same time a highly diverse society with more than 170 nationalities, Luxembourg represents a particularly interesting case. As the recent PISA studies have repeatedly shown, the Luxembourgish school system (including its traditional trilingualism and strong orientation on language education) produces a high degree of inequality, and represents an important challenge especially for children of migration.

With our study, which is based on in-depth interviews and which adopts an analytical approach combining elements of content and discourse analysis, we found a tendency towards a backward oriented idealized orientation of the past and a high degree of insecurity. We also show which ambivalences the teachers are confronted with and their efforts to deal with these ambivalences.

We hope to contribute to a deeper understanding of how teachers position themselves vis a vis the existing diversity in schools, and which discourse and argumentation patterns they rely on. We see this study as part of research on

*Corresponding author: Jean-Marc Wagner, University of Luxembourg, Faculty of Humanities, Education and Social Sciences, Department of Humanities, Maison des Sciences Humaines, 11, Porte des Sciences, L-4366 Esch/Alzette, Luxembourg, E-Mail: jeanmarc.wagner@uni.lu Adelheid Hu, University of Luxembourg, Faculty of Humanities, Education and Social Sciences, Department of Humanities, Maison des Sciences Humaines, 11, Porte des Sciences, L-4366 Esch/ Alzette, Luxembourg, E-Mail: adelheid.hu@uni.lu 
teacher professionalization that will be useful for reflexive pre- and in-service teacher training.

Keywords: Teacher professionalization, diversity, Luxembourg, educational discourse, discourse analysis

\section{Introduction}

Linguistic and cultural diversity in today's societies has become a central topic within research in humanities and social and educational sciences (Vertovec 2007) - and in investigating this theme, the Grand Duchy of Luxembourg represents a particularly interesting case. Luxembourg has a long multilingual and multicultural tradition. When it was established in 1839 it was officially given the status of a bilingual (French/German) country, subsequently becoming a trilingual country in 1984 when Luxembourgish was assigned the role of "national language" (Hu and Wagner in press). Moreover, Luxembourg is characterised by high levels of immigration and border crossing.

Since the 1960s the population has nearly doubled (STATEC 2018). Recent demographic statistics show that almost half of the population are foreigners from multiple countries within Europe and beyond, and that approximately 167,000 cross-border workers, mainly from neighbouring countries, come to Luxembourg every day. Luxembourg is home to several major European institutions including the European Court of Justice and the European Court of Auditors.

This complex diversity can also be observed in the country's educational institutions, which have only recently begun to make gradual efforts to adapt to the constant societal changes at work. Given its multilingual tradition, the school system is trilingual (Luxembourgish, German, French), and in addition to this, other languages are taught as foreign languages - such as English which plays an increasingly important role. Most teachers are Luxembourgish, but many have studied in neighbouring countries and bring a variety of teaching methods and traditions to their classrooms. School populations are also very diverse, especially in terms of the pupils' cultural, social and linguistic backgrounds (MENJE 2018a, 2018b). The challenges for teachers and for the education system as a whole are growing, and it is increasingly evident that traditional educational policies based on a Luxembourgish-speaking school population are becoming less appropriate and fair (SCRIPT and LUCET 2016, MENJE 2018a, OECD 2019). One of the primary pedagogical goals in Luxembourg today is the development of an innovative and more flexible educational culture that incorporates a variety of teaching approaches and strategies to cope with these societal transformations. 
There is also an ongoing debate on Luxembourgish identity and identification, especially related to linguistic and cultural homogeneity and heterogeneity and questions of integration, belonging and social cohesion (see Horner 2007 for the discourse on hybridity and purity of the Luxembourgish identity). In these discourses, the construction of difference - also in the sense of creating in- and out-groups - plays a central role. Some kinds of categorisation have become common practice, such as the differentiation between Luxembourgish-speaking children and children with other home languages (MENJE 2015; MENJE 2018b), or between Luxembourgers and "foreigners" (Peltier and Klein 2018; STATEC 2017). The more such social representations and categorisations are used in public discourse, the more they tend to be perceived as natural, normal, undeniable facts (Potter 2005).

Since teachers play a central role in the educational field, we have decided to concentrate in this chapter on the narratives of two Luxembourgish primary school teachers. Based on in-depth interviews, we particularly analyse their discursive constructions of homogeneity and diversity in Luxembourg and the way they conceptualise identity and difference. Our study is rooted in the research area of teacher professionalization, teacher narratives and identities in a multicultural and multilingual context.

\section{Teacher narratives about homogeneity and heterogeneity: Relevance of the topic and theoretical embedding}

School education is one of the most debated topics in the Luxembourg public sphere and often leads to heated discussions in traditional and social media (Forum 2017). The situation is characterised by a multitude of broadly controversial reforms and changes. To cite just a few examples, the Council of Europe's Language Education Policy Profile (2006) and especially the findings of PISA surveys highlight educational inequalities in terms of social origin and migrant background in the Luxembourgish school system (SCRIPT and EMACS 2013, OECD 2019). The traditional trilingual language regime in public schools (Luxembourgish in pre-school, literacy development in German at primary school before switching to French as the main language of instruction at secondary school) is particularly identified as seeming to create unfair conditions for pupils with other language and cultural backgrounds (SCRIPT and LUCET 2016). Since 2001, numerous reforms have been introduced with the aim of bringing about a systemic transformation, but these reforms have mostly failed in their implementation be- 
cause of a strong conservative resistance, especially at secondary level (Hu et al. 2015). Since the change of government in 2013, new educational pathways have been introduced, with alternative types of school (e.g. international schools or schools with English as the main language of instruction) offering more flexibility within the hitherto relatively inflexible and rigid education system. Beyond the stronger role of English, the valorisation of so-called "home languages" is part of the ministerial discourse on language education and educational fairness, and inclusive education (in terms of integrating children with disabilities in regular classes) is encouraged. Since 2017, early childhood education has become multilingual (Luxembourgish/French plus explicit valorisation of "home languages"), a political initiative that led to intense, controversial debates, especially based on the fear that the Luxembourgish language will lose ground (L'essentiel 2017). The extent to which these reforms will actually reduce the inequity of the public school system will become clearer over time.

Teachers are at the centre of all these debates and reforms. They constantly have to adapt their teaching styles and strategies both to new political demands and to the everyday challenges within their classrooms. Furthermore, research on teacher professionalisation (Terhart 2010), on the development of a professional identity (Kelchtermans 2009) and on teachers' narratives, beliefs and ideologies (Connelly and Clandinin 2000; Fives and Buehl 2012; Razfar 2012) has shown that the successful implementation of new policies depends strongly on teachers' attitudes, convictions and beliefs. Teachers' ideologies are socially constructed in narratives but rooted in a personal and biographically shaped value system (Reusser and Pauli 2011).

An urgent question in this context concerns teacher education and in-service teacher training. Reflection on one's own beliefs and values plays a key role in innovative forms of teacher training in order to avoid superficial measures that do not lead to sustainable improvement (Abendroth-Timmer 2017; Hu, Schank and Wagner 2018).

On the basis of a larger project on the self-positioning and discourse patterns of Luxembourgish teachers within this highly diverse setting (Wagner forthcoming) we focus for this chapter on two particular teacher narratives and concentrate on the following questions: What ideologies concerning language, culture and identity do the teachers draw on? How do they construct difference and homogeneity, i.e. how is difference/homogeneity "accentuated, negotiated, bracketed or suppressed” (Fairclough, 2003, pp. 40-41; see also Budde, 2017; Edelmann, 2006)?

Two theoretical concepts play a central role in this research: identity and difference.

First, it can be stated that identity and difference are core concepts within the domain of human meaning-making and perception of the world. As Straub states: 
"Differences and difference come to our attention continuously, synchronically in representations of the world as well as (diachronically) in representations of the past and the future." (Straub 2002: 63).

Beyond this, the construction of difference includes classifications and preconstruction. Fairclough (2003) reiterates this point clearly:

"What is at issue here is classification, preconstructed classification schemes of systems of classification, naturalized preconstructions (...) that are ignored as such and which can function as unconscious instruments of construction (Bourdieu and Wacquant 1992), preconstructed and taken for granted, 'di-visions' through which people continuously generate 'visions' of the world." (Fairclough 2003: 130; see also Mecheril 2018 and his notion of “code orders of belonging”).

The same goes for the concept of identity, which is directly interconnected with "difference". Talking about the identity of something often involves the construction of difference. As Woodward stresses:

"Often, identity is most clearly defined by difference that is by what it is not. Identities may be marked by polarization, for example in the most extreme forms of national or ethnic conflict, and by the marking of inclusion or exclusion - insiders and outsiders, 'us' and 'them'.” (Woodward 2002: 1-2).

It must however be stressed that in identity theory, alternative concepts of identity have been developed - concepts that critically call into question any kind of essentialist conceptualisation of identity in favour of a close interconnectedness between identity and language - language understood as discourse and narrative. Concepts that essentialise identity are characterised by the notion that there are stable identities with an essence that is independent of the surrounding society and discourse. In contrast to these positions, post-structural and deconstructivist theorists understand identities as narrative identities, and/or interactively constructed subject positions constituted through language; they are constructed within, not outside discourse (Hall 2000: 23, Hu 2014).

\section{Methodological approach}

As already mentioned above, the two cases presented here, are part of a larger PhD-project, which investigates six cases and includes broader research questions, e.g. the question of teachers' positioning and agency. In this chapter, we focus on two cases, which are especially rich concerning the construction of difference and homogeneity.

The framework of this project is embedded in socio-cultural constructivism which postulates that the perception of reality is based on constructed patterns of orientation and mental representations (Berger and Luckmann 1967). This leads 
to the assumption that the definition of reality is subject to an active "construction" process that can - at least to some extent - be de- and reconstructed in the research process.

In order to investigate and reconstruct these orientation patterns, we chose to rely on a combination of narrative and semi-structured interviews. Although we are aware that knowledge in interview research is always co-constructed (Miller 2011), these specific types of interview take the participants' perspectives into account, and participants are able to create narratives that are guided by their own orientation patterns (Razfar 2012, Schütze 1983: 286, Schulze 2013).

In order to focus on a number of specific and theory-driven aspects, the narrative interview was followed by a semi-structured interview. The questions concerned the teachers' perception of how they deal with diversity among pupils, how they perceive the developments in schools and their own role as teachers, among other topics.

We chose this particular combination of interview forms because it combined the teachers' subjective self-positioning (Lucius-Hoene and Deppermann 2004) on two levels: they based their argumentation on both autobiographical resources and their professional identity including their specialist knowledge. This allowed us to extract specific multi-dimensional in-depth data from the narratives.

In terms of sampling strategies, we chose a purposeful sampling to select the teachers according to the following criteria:

- They speak Luxembourgish and have no migration background (this represents the dominant proportion of primary school teachers due to the official recruitment criteria, e.g. knowledge of Luxembourgish, German and French)

- They have at least ten years of professional experience as a teacher (this makes it more probable that they can look back on a development in their professional biography)

- They work in schools where the catchment areas are composed of different socio-economic backgrounds with a high level of socio-cultural and linguistic diversity (based on the statistics of the Ministry of Education 2015)

We decided to rely on minimal variation sampling to reconstruct on the one hand structural similarities, and on the other hand, the variety of particularities found in the different argumentation patterns (Kleemann, Krähnke and Matuschek 2011).

The interviews were captured with a recording device and transcribed based on a slightly altered GAT transcription guideline (Langer 2013) that also takes into account breaks and non-verbal responses (such as laughter, throat clearing, loud inhalation, etc.). They lasted around three and a half hours each and were conducted in Luxembourgish language. 
For the data analysis, we combined elements of a number of approaches: firstly, we viewed the data on a content level (Mayring 2010), summarised the core messages and identified the main topics of each interview. Based on these topics, we developed categories of analysis that were used to code the material (Schmidt 2013).

As content and discourse cannot be separated (Wood and Kroger 2000: 7), we then examined the narratives by using elements of discourse analysis in order to extract the underlying ideologies and mind-sets (Fairclough 2003; Bamberg, De Fina and Schiffrin 2011).

Given the restricted length of this article, we cannot present all the steps of analysis. In the section below, we will therefore directly present the main themes that the teachers rely on when constructing their vision of homogeneity and heterogeneity, i.e. the collective parenting tradition, views on institutionalized childcare, the sociocultural background, the linguistic heterogeneity and the identity of the pupils. For each topic, we will illustrate and analyze the argumentation patterns on the basis of some significant quotations by using thematic analysis, but also including elements of discourse analysis such as the analysis of metaphors, the use of pronouns or the construction of a contrast between (an ideal) past and (difficult) present times.

\section{Analysis}

\subsection{Teacher profiles}

By their own accounts, both teachers were raised in carefree, protected environments in rural villages with a low percentage of foreigners. Both have Luxembourgish as their first language and are fluent in German, French and English. They had no difficulties at school and describe their educational path as being typical for their time. They both went to relatively prestigious secondary schools. I1 completed three years of teacher training in Belgium while I2 studied for two years at the Institut supérieur d'études et de recherches pédagogiques (ISERP - the Luxembourg Teacher Training Institute). I1 has been working as a teacher for 25 years and $\mathrm{I} 2$ for 35 years. Both work in schools with a relatively heterogeneous population: The catchment areas of their schools are defined by a high socio-economic status (60-65 on the ISEI scale), which is also reflected in a relatively high number of students ( $60 \%$ ) who opt for enseignement secondaire classique (classical secondary education as opposed to the less prestigious technical stream) (MENJE 2015). In the school setting of I1, only $35 \%$ of families have Luxembourgish as their first language and in I2's school, the figure is around $60 \%$. 


\subsection{Construction of homogeneity and heterogeneity}

\subsubsection{Collective parenting tradition}

During the interviews, both teachers refer to a notable change in the parenting tradition in recent years in Luxembourg. In their view, there was a collective consensus in the past on how children should be educated and these standards were valid for everyone. The teachers emphasise that the entire population was more homogeneous because of this parenting tradition:

The children's population has changed (.) eh as a result, schools have had to adapt too, of course (.) it has become more diverse, there are more (.) in the past (.) eh the population was more homogeneous if only because there were more Luxembourgers and fewer foreigners (.) in the past, the parenting consensus was clearer, today it is not clear (.) that is, how do I bring up my children (.) is a discussion that was not held, at that time, they were brought up as (.) it was tradition=definitely for most people. ${ }^{1}$

[D'Populatioun huet sech geännert vun de Kanner (.) eh doduerch huet Schoul sech missten natirlech och adaptéiren (.) et ass méi divers ginn et sinn méi (.) fréier war (.) eh d'Populatioun méi homogen alleng schon duerch et waren méi Lëtzebuerger an manner Ausläner dabei (.) fréier war och den Erzéihungskonsens méi kloer, haut ass deen net kloer (.) dat heescht wei erzéihen ech meng Kanner (.) ass eng Diskussioun déi fréier net sou gefouert ginn ass, do sinn se sou erzunn ginn, wéi se eben (.) wéi dat d'Traditioun war=bei villen Leit jiddefalls. (13191325, I2)]

I2 describes the (school) population as more homogeneous in the past by referring to the category of nationality and parenting. He argues that there was a collective consensus on parenting based on a collectively shared tradition and that this has changed with the transformation of society.

I1 puts forward a comparable argument, saying that in the past, the "structure" of pupils was "similar" because they had "similar manners and habits". In her view, there is no longer any "common ground", because what is true for one person does not hold true for others:

The society became more individualistic (...) that is a big difference, at the time most of the children were similar (.) they were different and yet similar in their structure but this is not true for today (.) I would say that in every home the manners were similar, the habits were quite similar and that is no longer the case today (.) what is true for one is not at all true for another [...] you have, how can I put it, no common ground any more.

1 We present the original quotations in Luxembourgish and a translation into English, because we want to respect the authenticity of the teachers' voices 


\begin{abstract}
[D'Gesellschaft ass méi individualistesch ginn (..) dat ass e groussen Ennerscheed, soss haaste am Fong geholl déi meescht Kanner waren ähnlech (.) si waren verschidden an awer an hirer Struktur ähnlech an dat ass haut net méi wouer (.) ech soen lo bei jiddfrengem doheem waren awer bëssen=d'Manéieren waren (.) ähnlech, d'Coutumen waren zimlech ähnlech an dat ass haut guer net méi sou (.) wat fir een wouer ass ass fir deen aneren guer net wouer [..] du hues keng, wei soll ech dat soen, keen gemeinsamen eh Nenner méi sou direkt (1215-1225, I1)]
\end{abstract}

In this statement, I1 attributes homogeneity in pupils" "structure" to shared "habits" and "manners". She suggests that similar parenting methods lead to a shared perception of reality ("what is true for one is not at all true for another"). The disappearance of collectively shared norms for parenting results in the loss of a "common ground". In her argument, homogeneity is a prerequisite for finding common basis for communication, and for agreeing on "what is true".

Both teachers seem to build their arguments around a threefold belief: firstly, that there is such a thing as a collective parenting tradition; secondly, that a collective parenting tradition is a condition for the creation of a homogeneous population; and thirdly, that this collective tradition has been lost in today's pluralistic society.

In the teachers' narratives, the transformation from homogeneity to heterogeneity has an influencing effect on the general tasks of teachers. In the past, teachers would have taught one homogeneous group, but today there is no longer this homogeneity; classes are separated into smaller heterogeneous groupings that need individual teaching, and teachers need to focus their attention mainly on those students that are experiencing difficulties:

I think previously one simply taught one group, globally (..) and the others came more or less along (.) and at the moment the main focus is simply (..) on how can I get those students through that can't keep up [...] At the time, you had a more homogeneous group (.) it was not homogeneous, but it worked that way (...) and now most classes no longer work as a homogeneous group, but more heterogeneous, so to speak, and you care more for one specific group than for the mainstream.

[Ech mengen virdrun huet een einfach ee Grupp ënnerriicht, global (..) an di aner sinn sou plus minus mat derduerch gangen (.) an am Moment ass den Haaptfokus einfach (..) wéi kann ech déi mat virun kréien déi net eenz ginn [...] Soss haaste méi su een homogenen (.) en war zwar net homogen mä en huet awer sou funktionéiert (..) an lo fonktionéiren déi meescht Klassen net méi als homogen Grupp mä su éischter su als (...) méi sou hétérogen souzesoen (..) dasste een Grupp méi betreits wéi de Mainstream (1204-1207, I1)]

According to I1, there is a shift in focus away from the "mainstream", i.e. from normal, average pupils towards a small group of children experiencing difficulties at school. In her opinion, this leads to a lowering of the general standards and requirements for students, meaning that good students are no longer receiving enough support and have to "adjust downwards": 
At the moment we are on a path where we do not take out the best of the really good (.) students because they have to adjust downwards (.) and because we currently use a lot of energy to address (..) those children with specific needs and therefore=because there are not enough means=I think we neglect we (.) neglect the very good students

[Am Moment sinn fannen ech datt mir op engem Wee sinn wou mer aus deene ganz gudden (.) Schüler (..) net dat Bescht raushuelen well si sech mussen no ënnen upassen (.) an well mer am Moment immens vill Energien drop verwenden fir (.) aus (..) deene Kanner mat spezifeschen Besoin'en=fir do op déi anzegoen an dowéinst=well net genuch Moyen'en do sinn=fannen ech verloossen mer eh vernoléissegen mer di (.) ganz gutt Schüler (921-926, I1)]

She links this transformation to the loss of common values in parenting and the efforts that parents put into their children's upbringing. For her, parents who instill values in their children at home are the exception.

Parents of children who still care for good upbringing and values (...) this seems to be currently a fringe group, this is no longer the normal standard, but rather the exception.

[Eltren vun (.) Kanner déi nach fir d'Erzéihung an Werter gesuecht hunn (...) dat schingt am Moment sou eng Randgrupp ze sinn (..) dat ass net méi normal de Standart mä dat ass éischter schonn sou d'Exceptioun (1186-1189, I1)]

I1 defines pupils who have been brought up on the basis of certain values and traditions as being the norm. By suggesting that they have now become an exception, she argues that this "regular" student is no longer the standard.

In this context, marginalisation plays an important role. The current development of society and school seems to give rise to a certain worry that the average "standard" student with a "good upbringing" will be dragged to the edge of the school focus, thus losing his or her dominant position as the desirable norm.

I 2 associates the loss of a common parenting tradition with increased insecurity among parents, which leads to difficulties for children in school. In his view, this can be observed in pupils' behaviour in school and creates obstacles for them:

We have children with orientation problems when they come to school, because at home they have had an upbringing characterised by uncertainties. The parents are becoming more and more insecure [...] in the past it was easier because the norms were handed down and today these traditional norms are not good for everything any more, that makes it partly difficult for the children.

[Et huet ee Kanner déi herno Orienteirungsproblemer hunn wann se dann an d'Schoul kommen well se doheem (..) ehm (.) eng Erzéihung haten déi jo vun den On=vun Onsecherheeten also d'Eltren sinn zunehmend onsecher [...] dat war fréier am Fong méi einfach well et huet een 
d'Normen wann net iwwerliwwert kritt an haut kritt een déi iwwerliwwert sinn Normen net méi (.) eh net méi fir alles gutt (.) et mëscht de Kanner et deelweis schwéier (1338-1344, I2)]

For I2, traditional parenting norms were "handed down" in the past and those norms served as universally valid guidelines ("good for everything”). With the disappearance of those norms, the parents became "insecure" and this insecurity would reflect itself in "orientation problems" of the children. So, according to I2, the insecurity of parents owing to a loss of generally accepted and valid parenting norms influences the children's development in a negative way.

Both teachers perceive and describe the current transformation of the school population as being the result of the disappearance of a collectively shared parenting tradition (among other factors). In their view, the lack of a parenting consensus leads to the disappearance of a homogeneous group.

\subsubsection{Institutionalised childcare}

Both teachers insisted on the view that modern parenting is marked by a tendency to hand over educational responsibility to a day care institution, which in turn has further detrimental effects on the development and school achievements of children. According to both teachers, in the past children were educated at home with only very few reference persons. Nowadays they spend most of their time in childcare centres (maisons relais) with various caretakers.

I ask myself questions, what does that mean for the children when you are suddenly in such a world where you no longer have anchor points? [...] An anchoring in a relationship, in a relationship with parents, in a relationship with very few people.

[Ech stellen mer do Froen wat bedeit dat fir d'Kanner wannste beemol an sou enger Welt bass wouste (.) deng Ankerpunkten net méi richteg [hues]? [...] D“Verankerung an enger Bezéihung, an enger Bezéihung mat Elteren, an enger Bezéihung mat weinegen Leit. (1380-1394, I2)]

I2 suggests that children with a limited number of reference persons develop a certain stability and find support in a specific "anchor point". The metaphor of "anchoring" is particularly interesting because it shows that for I2, the concept of stability and attachment to a fixed and solid foundation is central to his argument. According to I2, children who have to stay before or after school in childcare centres are not "anchored" in a solid foundation, which leads to instability and emotional distress. I2 describes the negative effects of this institutionalised socialisation from observations made in his own classroom: 
We notice, for example, that those children cared for at home are often more stable in school than those cared for in an institution [...] We increasingly have those who can't concentrate, with emotional control that is not as it should be, who are tired, who are (...) agitated.

[Mir mierken awer zum Beispill dass déi Kanner di doheem betreit ginn oft schoulesch eh och eng eh méi stabil sinn wéi déi déi an enger Institutioun betreit ginn [...] mir hunn der zunehmend déi net konzentréiert sinn, d'Emotiounssteierung net sou ass wéi se soll sinn, déi eh midd sinn, déi eh (.) agitéiert sinn. (1419-1434, I2)]

According to I2, pupils coming from day care centres are seen as behaving in an inappropriate way and do not meet the desired standards in the classroom ("can't concentrate", "tired", "agitated"). The use of the pronoun "we" emphasises that this perception not only reflects his own observations but also those of his fellow teachers, thereby transforming this particular distinguishing feature into a generally accepted perception. From his perspective, these negative effects arise when pupils attend a day care centre rather than being educated at home.

I1 links pupils' attendance at day care centres with their school performance. In her view, children that stay at home can study with their parents and thus have an advantage over those who attend day care centres.

There will be no justice because you always have those parents who study at home with their children, [who] are always at an advantage over those who are 20 in a day care centre.

[Gerechtegkeet gëtt et net domat well du hues awer ëmmer di Eltren déi doheem mat hiere Kanner léiren sinn awer ëmmer am Virdeel par rapport zu deenen dei zu 20 an der Maison Relais sinn. (1074-1076, I1)]

She associates justice in education with equal starting points for all students. According to her statement, an equality cannot be achieved because the daycare centres can't equalize the advantage of parents who support their children individually at home.

In terms of school success, she attributes an important role to extra-curricular supervision in reducing or increasing inequality by connecting students' success in school with parents' efforts to educate their children. She transfers the responsibility for reducing educational inequalities from school to extra-curricular supervision.

By differentiating along the category of institutionalised socialisation, both teachers construct an unbalanced power hierarchy among students. The desired norm is based on children that are educated at home, as opposed to children who spend their time in day care centres. 


\subsubsection{Socio-cultural background}

Another category that the teachers use to differentiate among their students is their socio-cultural background. They refer to the social environment of students to explain their behaviour and their performance at school. I2 establishes a relationship between social environment, the importance attributed to school and the achievements of students:

The importance of school for the parents ehm not everyone is aware that school is so importan$t=$ according to which milieu you come from it is ehm it is difficult to explain to the parents that it is actually worth investing in the learning of their children, time-wise but also effort-wise.

[De Stellenwert vun der Schoul bei den Eltren ehm net jiddereen ass sech bewosst dass d'Schoul sou wichteg ass=deemno aus wéiengem Milieu dasste kenns dann ass ehm ass et schwéier den Eltren bäizebrengen dass et schonn interessant ass ehm an d'Léieren vun de Kanner ze investéieren, zäitlech gesinn an och vum Effort hier. (692-696, I2)]

In this quotation, I2 links socio-cultural environment to the importance that parents attach to school. It is claimed that parents from a specific social environment do not understand the significance of school and therefore do not invest time and effort in their children's education. I2 suggests that this creates a situation where some children are not successful in school because they come from a particular social environment. I1 creates a similar link between students' environment and their performance in school:

If someone comes from an environment where it [school] is not important or has no resources, then I can understand more easily that for him, school is basically something (...) he does not take seriously.

[Wann] een aus engem Emfeld kennt wou dat guer net wichteg ass oder deen guer keng Moyen'en huet (.) kann ech besser verstoen datt dat fir deen am Fong geholl einfach eppes ass wat en (..) wat en guer net serieux hëllt (945-947, I1)]

Here too, I1 makes a link between social origins, pupils' resources and achievements in school. I1 tries to explain undesired behaviour ("not taking school seriously") by referring to the family environment.

I2 also argues that family background plays a major role in categorising the students.

I do not go to parents' homes on a regular basis, but sometimes I then also go (.) I also go to the homes of foreigners to take a look because (breathing in) when you see how the conditions are, you also understand why the child does not have some things or cannot possess them. 
[Ech ginn net regelméisseg bei Eltren mä ech ginn heinsdo awer och dann=och bei Auslänner ginn ech dann mol heem kucken well (einatmend) wann een dann gesäit wéi d'Konditiounen sinn versteet een och firwaat dass d'Kand verschidden Saachen net huet oder net kann hunn $(1521-1524$, I2)]

In his view, there is a connection between the family background and the student's appearance in school. In this quotation, I2 associates "foreigners" with unfavorable conditions at home, and refers to it as an explanation why a child can or cannot have the necessary equipment in school.

According to both teachers, in the past socio-cultural background was a highly relevant category to differentiate among students and explain their behaviour in school. However, in their view this distinction is no longer sufficient for classifying their students. They believe that nowadays a greater number of variables shape children and this leads to several other distinguishing criteria. The different nationalities, traditions, cultural backgrounds and belief systems of students are central to this transformation:

So it has always been diverse but now it is even more diverse I would say (.) in the past, you also had socially weak, socially strong, you had eh (.) also distinct milieus, it has been like that forever, this is quite normal but at the moment, diversification is increasing [...] the fact that you have even more (...) more nations, more traditions, more cultural backgrounds, more life experience, more belief systems and this is basically happening more and more.

[Also et war nach ëmmer verschidden mä et ass lo nach méi verschidden giff ech mengen [...] fréier haaste och sozial schwach, sozial staark du haas eh (.) och divers Milieu'en dat war nach ëmmer sou, dat ass jo och (..) normal an am Moment kommen dann nach (.) also d'Diversifizierung hellt zou [...] Doduerch dass een dann nach méi (..) dass nach méi Natiounen, méi Traditiounen, méi kulturell Hannergrënn, méi (.) méi eh Liewenserfahrung, méi Glaawens eh richtungen an dat hëllt am F=dat gëtt, dat gëtt nach méi (1576-1587, I2)]

I2 argues that in the past, there were also differences between the children, but those differences were easier to handle because they were based mostly on the different socio-economic status of the children: you only had to refer to socially weak or strong environments. However, nowadays the categories of socially strong or weak no longer suffice. In the school context, I2 underlines that this increases the demands on schools, because they need to take into account a multitude of other variables to respond to each child individually:

Basically (.) every child has always (.) needed something different (.) but now they need a lot more (.) well in the past the one who was good at languages, has=is (...) certain demands with regard to the school (.) has always been a=well it is a utopia to think in the past everything was equal, it wasn't like that (.) but I think that the demands of those different eh (.) children towards school are greater than what school can almost manage [...].I cannot make everyone $=$ I can't meet the needs of each one individually 


\begin{abstract}
[Am Fong (.) huet nach ëmmer all Kand (.) eppes aneschters gebraucht (.) awer lo brauchen se nach méi aner Saachen (.) ehm also fréier huet deen een dee gudd Sprochen konnt, deen hue=ass (..) den Usproch un d'Schoul (.) war nach ëmmer eng=also et ass eng Utopie ze mengen fréier wär alles gläichgeschalt gewiecht, dat war jo och ni esou (.) mä ech mengen dass eh d'Usprech déi vun deenen verschiddenen eh (.) Kanner do un d'Schoul gestallt ginn, méi grouss sinn wéi dat wat d'Schoul baal kann leeschten [...] ech kann net jiddereng=also ech kann net d'Besoin'en vun jidderengem individuell (1593-1598, I2)]
\end{abstract}

In the past, addressing different needs was easier, but nowadays, the increasingly diverse backgrounds of children require a much greater effort. He argues that teachers can no longer satisfy students' needs and are overstrained with these excessive demands due to diversity.

\title{
4.2.4 Linguistic heterogeneity
}

For both teachers, the linguistic heterogeneity of students is also important as a distinguishing category. They describe linguistic differences as less significant in the past. According to I2, the majority of pupils spoke Luxembourgish and the "few foreigners" learned it very quickly.

So it was easier at that time because every child could speak Luxembourgish, those who were not able to speak Luxembourgish were really exceptions so foreign children (...) ehm there were immigrants at the time, Italian immigrants, or maybe some Spanish or something, but then the kids could quickly speak Luxembourgish (.) that is, the language problem at the time was much less complex than it is today.

[„Also et war déi Zäit jo an sech méi einfach well jo ehm vun de Kanner jiddren Lëtzebuergesch konnt, déi déi net Lëtzebuergesch konnten waren wirklech Ausnahmen also Auslännerkanner (..) ehm et hat een déi Zäit Immigranten, italienesch Immigranten oder vläischt mol spuenescher oder sou wou d'Kanner awer dann awer schnell Lëtzebuergesch konnten och (.) dat heescht de Sprochenproblem war déi Zäit wesentlech manner komplex wéi lo (522-527, I2)]

I2 describes the language diversity of the children as being a problem that has become more complex over time. In his view, there was no apparent linguistic diversity in the past because the children had the same linguistic background. Nowadays, children can no longer refer to the same language repertoire, making linguistic diversity a "language problem". He creates homogeneity by projecting an identical language background on children in the past that has now been replaced by the current linguistic plurality. This increasingly linguistic diversity due to the emergence of "foreign children" is then depicted as a "technical problem" for teachers: 
Of course, the children's population has changed, there are more foreign children there [...] in principle this is not problematic it is only then how do I deal with the foreigners in terms of teaching it's more of a technical problem, how should I organise things? How much additional effort do I need to invest? How much help do I need? How can I organise myself? So often it is ehm sometimes you get the feeling that you have more problems than solutions (laughs) but that's the reality, so you just have to deal with that.

[Natirlech huet och d'Populatioun geännert vun de Kanner, et sinn méi auslänesch Kanner dabai [...] also prinzipiell ass dat net problematesch et ass just dann wéi ginn ech mat den den Ausläner ëm wat lo den Enseignement unbelaangt et ass éischter en techneschen Problem wéi muss ech mech organiséiren? Wéivill Opwand muss ech nach hunn? Wéivill Hëllef brauch ech? Wéivill individual, wéi kann ech mech organiséiren? Also oft ass et do ehm et huet een heinsdo d'Gefill dass een méi Problemer huet wéi een Léisungen huet (lacht) awer dat ass d'Réalitéit, also do muss een einfach domat eenz ginn. (1345-1352, I2)]

The teacher regards the diverse linguistic backgrounds among students as problematic, since those students cannot be integrated into the usual daily school routine without additional effort. Here again, I2 expresses the feeling of being overwhelmed by the task of dealing with heterogeneity. He associates the linguistic diversity of his students with a situation that requires help and leads to more problems than solutions. In his argument, there is a certain degree of powerlessness and helplessness, as well as the feeling of having to surrender to the situation without actively being able to change it. By defining this problematic situation as an unchangeable reality, I2 reduces his ability to actively influence the situation. It is remarkable that, in this context of linguistic diversity, he uses the strong metaphor of "damage limitation":

Youjust have to resignyourself to that and then you cannot saywell is itgood or bad? That question is completely superfluous (.) now it's like this and now you have to try to do damage limitation.

[Et muss een sech deem einfach fügen an dann kann een net gutt soen ass dat gutt oder schlecht? Déi Fro ass dann komplett iwwerflësseg dann och (.) et ass dann mol esou an dann muss een kucken fir Schadensbegrenzung ze machen. (1630-1632, I2)]

I2 sees his role as a teacher to minimise the "damage" resulting from linguistic diversity. It is not clear what kind of "damage" he is referring to, but it seems obvious that language is depicted as a severe problem.

Furthermore, he expresses the feeling that the strong emphasis on languages in the Luxembourgish education system is a heavy burden for the students:

The focus on languages becomes partly=it has always been a burden=but now it may even become a bigger burden that stands out because there are alternative [educational options] and also because linguistic diversity is increasing. 
[Déi Sprochenlaschtegkeet gëtt zum Deel=et war nach ëmmer eng Belaaschtung=mä et gëtt vläit lo méi eng Belaaschtung déi opfällt wellste alternativ [Bildungsméiglechkeeten] hues an well och duerch d'Sprochenvielfalt dann zouhëllt. (674-676, I2)]

For foreigners, however, it would be even more difficult because of their linguistic diversity. According to him, students with a diverse linguistic background cannot rely on their mother tongue to be successful in the Luxembourgish school context:

We had a family from Ireland [...] where you thought to yourself: 'Oh God, now they come here, now they have to learn German and French, the English can be forgotten again' [...] for these children, it really is agony when they are not allowed to do the only thing they are able to do and have to learn many new things.

[Aus Irland haaten mer eng Famill [...] dann denkste der "Oh Gott lo kommen déi hei, lo mussen déi Däitsch a Franséisch machen, dat Englescht kënnen se rëm vergiessen [...] fir déi Kanner ass et wirklech eng Qual wann se dat eenzegt wat se kennen dierfen se net maachen an si mussen lauter nei Saachen léieren. (681-687, I2)]

His view implies a certain perspective on how language learning occurs in the trilingual Luxembourgish school system for newcomers: the first language does not serve as a resource or basis to learn an additional language; the student even "has to forget it”. For non-Luxembourgish-speaking students, learning a new language is depicted as an "agony" and obstacle in the student's educational path.

A similar reasoning can be found in the arguments of I1. For her, linguistic diversity has increased with migration and can be considered as a "barrier" instead of an added resource.

Furthermore, I think we have (4sec) a migration of (...) and this makes things more difficult. I think if you have a language barrier then (.) yes that does not make things easier.

[Des ferneren hunn mer geng ech soen (4sec) eng Migratioun vun (...) an dat mëscht och ëmmer d'Saach schwéier well ech mengen wannste (.) eng Sprochebarrière hues dann (.) jo dat erliichtert d'Saach net. (Z.855-857, I1)]

What is interesting here is that I1 does not connect migration to a certain category (such as nationality for instance). We cannot explain why she avoids naming a specific category; however, what we can extract from her statement is that she makes a difference between two groups: those who have difficulties owing to their language background and those who do not have these language barriers. This seems to be independent of the national background; it is more of an implicit distinction between outsiders ("them" - children with a migration background and a language barrier) and insiders ("us" - children without migration background and not having this language barrier). 
In addition to the loss of collectively shared traditions, she argues that the diversity of languages and cultural backgrounds makes it difficult to find a "common basis":

Yes but the individual situation [...] makes it harder to find a common basis (..) if you cannot refer to the same customs [...] the language is not always identical (.) then I thin $k=$ Iaskmyself $=$ but then you have to ask yourself (...) the question on what eh with what do I now build the common basis.

[Jo mä duerch déi individuell Situatioun [...] ass et méi schwéier fir eng gemeinsam Basis ze fannen (..) wannste net méi kanns op déi selwecht Gebräich zréckgräifen [...] d'Sproch ass jo dann och net ëmmeridentesch (.) dann fannen ech=froen ech mech=dann muss een schonn awer sech (..) d'Fro stellen op wat eh mat wat bauen ech dann lo di gemeinsam Basis. (1257-1263, I1)]

This reasoning recalls what Horner (2007) has called the "purist discourse", in which the Luxembourgish language and national traditions function as enabling affiliation. In the teacher's view, there is a link between linguistic diversity and the loss of a common basis. It is interesting here that this common basis, to which I1 is referring, is not elaborated explicitly.

To summarise, we can say that both teachers use language diversity as a differentiating category. They share the view that the varied linguistic backgrounds of their students are an obstacle rather than an additional resource. This can be related to a deficit-oriented perspective on linguistic plurality (for a more detailed analysis of attitudes towards language education see Europarat and MENFP 2006; $\mathrm{Hu}$, Schank and Wagner 2018).

\subsubsection{Identity/Personality}

Although the concept of identity is already implicit in the previous categories, the teachers expand on it more explicitly in their narration about the negative effects of a changing society and communication practices. I2 associates the identity, in his words "personality", of the students with their language proficiency (for a detailed clarification of the concepts identity, personality and self, see $\mathrm{Hu} 2003:$ 81).

I have a few children at the moment, one in particular where I see this, who cannot speak any language, not even his mother tongue [...] I find that dramatic, because you define your personality a lot through language and if you cannot speak any language well, what happens? Where are you heading? Can you catch up again? The window for languages is there when you're little; at some point it becomes tedious and difficult.

[Ech hunn och lo e puer Kanner=een wou ech dat gesinn deen kann keng Sproch gudd och keng Mammesproch gutt [...] dat fannen ech dramatesch well een sech jo awer d'Perséinlechkeet vill iwwert d'Sprooch définéiert an wannste eng Sprooch (.) keng Sproch gutt kanns, wat (.) wat geschitt dann? wat (.) wou steierste dann hin? Kannste dat no huelen? Déi Sprochefensteren 
sinn do wannste ganz kleng bass, iegentwann eng Kéier gëtt dat mühsam an an eh schwiereg. (2426-2434, I2)]

In his view, children have problems defining their personality if they do not develop their "mother tongue" properly at an early age. From his point of view, children will have difficulties catching up on this, because the time window to learn a language is depicted as being very limited.

I1, on the other hand, links identity to cultural "roots" and traditions. If children do not have very clear traditions that allow them to be "rooted" in a cultural structure, they lose their "deep identity". It is argued that this is especially the case for boys (with a single mother) who do not function properly in school because they are not "anchored in any culture":

\begin{abstract}
But what gets lost is just (..) is the deep identity of a person ehm that somehow gets lost and I realise that I find that personally very problematic (.) not for children who function but for those who do not function, there I find it problematic, because they are no longer (..) they are no longer in any structure (.) yes I think that it is difficult for many pupils, mainly boys, no father present and then (.) not anchored in any culture, neither here nor there, nor anchored anywhere else, I find it difficult.
\end{abstract}

[Wat awer verluer geet dat ass eben (..) déi déif Identitéit vun engem ehm dat geet iegentwei verluer an ech mierken ech fannen dat perséinlech problematesch (.) net fir Kanner déi fonktionnéiren mä fir déi déi net fonktionnéiren, do fannen ech dat problematesch well di net méi (..) di sinn a kenger Struktur mi dran (.) an soss (.) jo ech denken datt dat fir vill (.) haptsächlech Jongen schwiereg ass (.) keen Papp do an dann (.) och an kenger Kultur richteg, weder nach hei do, nach soss iegentwou verankert, ech fannen dat schwiereg. (1228-1234, I1)]

She stresses that in order to develop a "deep identity", you would need to be "anchored" in a particular culture. Culture is depicted here as a solid entity that fixes and stabilises the structure of identity ("anchor point”), implicating an essentialist view on culture and identity. Since I1 speaks about standing between two cultures ("neither here nor there"), it is clear that she is not referring to the - in her view normal Luxembourgish pupil who seems fully rooted in one (the local) culture.

It is interesting that she refers only to students who do not "function properly" in school. In her argument, she tries to explain the pupils' failure to "function" in school by projecting her view of cultural instability onto these students.

Furthermore, I1 associates the increase of foreign students with different cultural backgrounds in the Luxembourgish school system with the loss of Luxembourgish identity and traditional values. I1 stresses that if the Luxembourgish public schools adapt too much to this increasing cultural diversity, they are risking the same fate as those foreign boys without a father: they risk losing their own traditions and identity. 
I think [school] adapts too much in the sense that in a German text (.) in a Luxembourgish German book (.) if you have suddenly (.) Emir and Amir and whatsoever and you do not have a single Josy and no Metty any more, then I think (.) we have adapted to the opposite and that (..) one should not completely give up one's own identity.

[Ech fannen si adaptéiert sech zevill an deem Sënn dasste an engem däitschen Text (.) an engem lëtzebuergeschen däitsche Buch (.) a wannste do e beemol (.) Emir an Amir an ech wees net wat an du hues awer keen eenzegen (.) Josy an keen Metty méi fannen ech (.) hunn mer eis an de Geigendeel adaptéiert an dat (..) et soll een net seng eegen (...) Identitéit ganz opginn. (1241-1245, I1)]

In this case, she depicts pupils with traditional Arabic names from Eastern Europe or the Middle East (Emir and Amir) as a replacement for traditional Luxembourgish names (Josy and Metty) in a typical Luxembourgish German textbook. She argues that if school allows too many different cultures, then there is a risk of losing one's own culture. It is remarkable how she stresses the dichotomy between own identity and foreignness.

She also elaborates the metaphor of being "rooted in a tradition" when she speaks about her own experience, highlighting that her socialisation was based on strong "roots" that are fixed in a stable tradition.

Honouring the tradition where you come from, so maintaining your identity (...) without falling into an extreme of (..) let's say nationalism or something like that=but just where do I come from, I find that very important, when=to know where you want to go, I think, you first have to know where, where your roots are=where you come from [...] rooted in a tradition.

[D’Traditiounen éieren, vun do wou een hierkënnt also seng Identitéit (...) pfleegen ouni lo an een Extrem ze verfaalen vun (..) ech soen lo vun Nationalismus oder sou=mä einfach wou kommen ech hier, dat fannen ech ganz wichteg, wann=fir ze wëssen wou een hiwëllt fannen ech muss een fir d'éischt mol wëssen, wou, wou seng Wuerzlen sinn=wou een hierkënnt [...] verwuerzelt an enger Traditioun. (96-103, I1)]

The repetitive use of several strong metaphors, such as "roots", "rooted", "not anchored in any culture" is obvious here and seems to reflect a strong emotional involvement and a tendency to essentialise identity, language, and culture (for a critical analysis on the metaphor of roots see Flusser 2007).

\section{Concluding remarks}

We started our chapter by describing the particularities of the Luxembourgish context, which is characterised by a long-standing tradition of multilingualism/ multiculturalism, immigration and border crossing. Despite this historically 
rooted diversity, the school system is not able to cope by adopting a "fair" educational approach, as even very recent studies show (MENJE 2018a, OECD 2019). Although Luxembourg has been a multilingual and multicultural country for many centuries, the school system is based on the assumption that most children speak Luxembourgish at home, i.e. on the assumption of linguistic homogeneity.

As existing research has shown, teachers and their beliefs, orientation patterns and ideologies play a central role in sustainable change. Although the Ministry of Education and many stakeholders are making a concerted effort to try to find innovative solutions for more flexibility and a child-oriented educational system, many previous reforms have failed.

Based on the narratives of two Luxembourgish primary school teachers we therefore concentrated on the following question: How do teachers construct difference and homogeneity?

As a result of our analysis, we were able to identify five themes that played a significant role in the teachers' perceptions of diversity/homogeneity: the collective parenting tradition, views on institutionalised childcare, socio-cultural background, linguistic heterogeneity and the identity/personality of the pupils. Within these themes, both teachers provided a detailed account of their understanding of diversity and homogeneity, norms and normality, their subjective theories on (language) learning, their fear of loss of identity and control and their concerns about marginalisation. Below is a summary of some of the overall findings:

1) When dealing with diversity, it is striking to observe the extent to which the teachers adopt a historical perspective when speaking about their school and their students. They create homogeneity (in the past) and heterogeneity (in the present) by referring to historical transition and argue that the transformation of society has brought about major changes in the school environment. They generally describe the past in a more positive light than the present. They emphasise that the population used to be more homogeneous, that the overall situation was easier to handle and that teachers were able to make greater demands on the students. They define the past by projecting an idealised homogeneity not only on the school population but also on society as a whole. By relating the present to an idealised past, they create a pejorative picture of modern childhood, suggesting that today's children are unable to develop properly. This backward-looking reasoning implies that none of the teachers is satisfied with the current situation, but they have not yet developed a future-oriented perspective in which changes are incorporated positively.

2) With regard to norms and the construction of normality, the teachers assess the presence or absence of certain characteristics and features of the students according to a predefined norm, which is generally related to the past. The 
construction of differences can create an unbalanced power relation between categories and an unconscious construction of hierarchical norms, if they are not reflected.

3) Both teachers expressed the feeling of being overwhelmed by the demands of the students. They both see the role of school to teach a collective or homogeneous group, rather than to address each pupil individually. In their view, the increase of diversity leads to a general decrease of the quality of teaching and learning.

4) Parenting and students' social backgrounds are depicted as being the main factors that influence the students' success at school. In attributing such importance to family background, the teachers distance themselves from their own impact on the development of their students.

5) As well as raising the problematic issue of diversity, the teachers express a fear of loss regarding their own traditions, which reminds of the discourse of linguistic and cultural endangerment, observable in the media and political discourses in Luxembourg (Purschke 2018). Moreover, they link the Luxembourgish cultural tradition with their own socialisation, which they worry, may gradually be dissolved due to the increasing plurality of the student body. The fear of diversification of society is thus linked to a fear of marginalization; in other words, by giving other cultures and languages too much importance and space, one may lose one's own cultural traditions and thus identity. The teachers therefore place considerable emphasis on the role of collectively shared cultural traditions and values.

6) Both teachers rely on an essentialised concept of identity and culture. They establish a specific connection between the development of a "deep identity" and the fact of being rooted in a cultural and linguistic tradition. They seem to be afraid that students will be lost between two cultures and will therefore become increasingly unstable and insecure in school. The use of essentialising metaphors such as "anchoring”, "anchor points", "rooted in one’s own culture”, etc. underlines this view.

To conclude, the analysis of discursive patterns within specific themes shows a high degree of feelings of insecurity. The two teachers create a largely pessimistic narrative about migration and diversity, and suggest that the presence of a diverse population creates more problems than benefits for school and society. The backward-oriented idealised interpretation of the past hampers a positive and constructive approach to a changing society. As Purschke (2018) recently pointed out, these discursive patterns seem to be generally quite prominent within the current political discourse in Luxembourg and are characterised by a strong culturally conservative attitude, including the fear of being "overrun by foreigners, 
the loss of cultural identity, the romanticising of the past and the desire for national boundaries in a globalised world" (Purschke 2018: 11).

It is evident that these findings cannot and should not be generalised. We only analysed two cases, and it will be important to include more participants in the overall study. Nevertheless it is surprising that the "fear of the other" (Bauman 2016) and conservative representations can be so prominent in a context that has had a multilingual and multicultural tradition for many centuries.

\section{References}

Abendroth-Timmer, Dagmar. 2017. Reflexive Lehrerbildung und Lehrerforschung in der Fremdsprachendidaktik: Ein Modell zur Definition und Rahmung von Reflexion. Zeitschrift für Fremdsprachenforschung 28(1). 101-126.

Bamberg, Michael, Anna De Fina and Deborah Schiffrin. 2011. Discourse and Identity Construction. In Seth J. Schwartz, Koen Luyckx and Vivian L. Vignoles (eds.), Handbook of Identity Theory and Research, 177-199. New York: Springer.

Bauman, Zygmunt. 2016. Strangers at Our Door. Cambridge: Polity Press.

Berger, Peter L. and Thomas Luckmann. 1967. The social construction of reality: a treatise in the sociology of knowledge. New York: Doubleday and company.

Budde, Jürgen. 2017. Heterogenität: Entstehung, Begriff, Abgrenzung. In Thorsten Bohl, Jürgen Budde and Markus Rieger-Ladich (eds.), Umgang mit Heterogenität in Schule und Unterricht, 13-26. Regensburg: Julius Klinkhardt.

Connelly, F. Michael and D. Jean Clandinin. 2000. Narrative Understandings of teacher knowledge. Journal of Curriculum and Supervision 15(4). 315-331.

Edelmann, Doris. 2006. Pädagogische Professionalität im transnationalen sozialen Raum. Eine Studie über Sichtweisen und Erfahrungen von Primarlehrpersonen in Bezug auf die kulturelle Heterogenität ihrer Schulklassen. In Ewald Terhart and Cristina Allemann-Ghionda (eds.), Kompetenzen und Kompetenzentwicklung von Lehrerinnen und Lehrern (Zeitschrift für Pädagogik - 51. Beiheft), 235-249. Weinheim: Beltz.

Europarat and MENFP. 2006. Profil de la politique linguistique éducative. Luxembourg: MENFP.

Fairclough, Norman. 2003. Analysing discourse: textual analysis for social research. London: Routledge.

Fives, Helenrose and Michelle M. Buehl. 2012. Spring cleaning for the "messy" construct of teacher's beliefs: What are they? Which have been examined? What can they tell us? In Karen R. Harris, Steve Graham, Sandra Graham, James M. Royer and Moshe Zeidner (eds.), APA Educational Psychology Handbook, vol. 2, 471-499. Washington: American Psychological Association.

Flusser, Vilém. 2007. Von der Freiheit des Migranten - Einsprüche gegen den Nationalismus. Hamburg: Europäische Verlagsanstalt.

Forum. 2017. Vielfalt in der Schule / Diversité à l'école. Forum für Politik, Gesellschaft und Kultur. Vol. 377. Luxembourg: forum a.s.b.l.

Friese, Heidrun. 2002. Identity: Desire, Name and Difference. Identities: time, difference, and boundaries, 17-31. New York: Berghahn Books. 
Gogolin, Ingrid. 1994. Der monolinguale Habitus der multilingualen Schule. Münster: Waxmann Verlag.

Hall, Stuart. 2000. Who needs identity? In Paul du Gay, Jessica Evans and Peter Redman (eds.), Identity: A Reader, 15-30. First edition. London ; Thousand Oaks, Calif: SAGE Publications Ltd.

Horner, Kristine. 2007. Language and Luxembourgish national identity: ideologies of hybridity and purity in the past and present. In Stephan Elspaß, Nils Langer, Joachim Scharloth and Wim Vandenbussche (eds.), Germanic Language Histories "from Below" (1700-2000) (Studia Linguistica Germanica 86). Berlin: Walter de Gruyter.

Hu, Adelheid. 2003. Schulischer Fremdsprachenunterricht und migrationsbedingte Mehrsprachigkeit. Tübingen: Gunter Narr Verlag.

Hu, Adelheid. 2014. Languages and Identities. In Christiane Fäcke (ed.), Manual of Language Acquisition, 87-102. Berlin: De Gruyter Mouton.

Hu, Adelheid, Marie-Anne Hansen-Pauly, Monique Reichert and Sonja Ugen. 2015. Mehrsprachigkeit im luxemburgischen Sekundarschulwesen. Bildungsbericht Luxemburg 2015 Band 2: Analysen und Befunde, 63-75. Luxembourg: Université du Luxembourg and Ministère de l'Éducation nationale.

Hu, Adelheid, Flore Schank and Jean-Marc Wagner. 2018. Language Awareness von Lehrkräften: Bildungsverläufe und professionelles Handeln. Nationaler Bildungsbericht 2018, 191-200. Luxembourg: Université du Luxembourg and Ministère de l'Éducation nationale.

Hu, Adelheid and Jean-Marc Wagner. In press. Zwischen Tradition und Globalisierung: Mehrsprachigkeit im Luxemburgischen Schulsystem. In Ingrid Gogolin, Antje Hansen, Paul Leseman, Sarah McMonagle and Dominique Rauch (eds.), Mehrsprachigkeit und Bildung. Wiesbaden: VS Verlag.

Kelchtermans, Geert. 2009. Career Stories as Gateway to Understanding Teacher Development. In Martin Bayer, Ulf Brinkkjær, Helle Plauborg and Simon Rolls (eds.), Teachers Career Trajectories and Work Lives, 29-49. Dodrecht: Springer.

Kleemann, Frank, Uwe Krähnke and Ingo Matuschek. 2013. Interpretative Sozialforschung. Wiesbaden: VS Verlag.

Langer, Antje. 2013. Transkribieren - Grundlagen und Regeln. In Barbara Friebertshäuser, Antje Langer and Annedore Prengel (eds.), Handbuch Qualitative Forschungsmethoden in der Erziehungswissenschaft, 515-528. 4th ed. Weinheim Basel: Beltz Juventa.

L'essentiel. 2017. Quelle place pour la langue luxembourgeoise? L'essentiel. http://www.lessen tiel.lu/fr/luxembourg/story/quelle-place-pour-la-langue-luxembourgeoise-20996965 (18 December, 2018).

Lucius-Hoene, Gabriele and Arnulf Deppermann. 2004. Narrative Identität und Positionierung. Gesprächsforschung - Online-Zeitschrift zur verbalen Interaktion 5. 166-183.

Mayring, Philipp. 2010. Qualitative Inhaltsanalyse. In Günter Mey and Katja Mruck (eds.), Handbuch Qualitative Forschung in der Psychologie, 601-613. Wiesbaden: VS Verlag.

Mecheril, Paul. 2018. Orders of Belonging and Education: Migration Pedagogy as Criticism. In Doris Bachmann-Medick and Jens Kugele (eds.), Migration: Changing Concepts, Critical Approaches. Berlin, Boston: De Gruyter.

MENJE. 2015. Bildungsbericht Luxembourg 2015. Band 1: Sonderausgabe der Chiffres clés de l'éducation nationale 2013/2014. Luxembourg: Ministère de l'Éducation nationale.

MENJE. 2018a. Bildungsbericht Luxembourg 2018. Luxembourg: Ministère de l'Éducation nationale \& University of Luxembourg. 
MENJE. 2018b. Les chiffres clés de l'Éducation nationale: statistiques et indicateurs 2016-2017 / The key figures of the national education: statistics and indicators 2016-2017. Luxembourg: Ministère de l'Éducation nationale.

Miller, Elizabeth R. (2011). Indeterminacy and interview research: Co-constructing ambiguity and clarity in interviews with an adult immigrant learner of English. Applied Linguistics 32 (1), 43- 59.

OECD. 2019. Programme for international student assessment (PISA) - Results from Pisa 2018. https://www.oecd.org/pisa/publications/PISA2018_CNT_LUX.pdf

Peltier, Francois and Charlie Klein. 2018. Regards sur la population $N^{\circ} 7$. Luxembourg: STATEC.

Potter, Jonathan. 2005. Representing reality: discourse, rhetoric and social construction. London: Sage.

Purschke, Christophe. 2018. Auf der Suche nach dem verlorenen Zeug - Über Geschichte und Zukunft im politischen Diskurs. Forum für Politik, Gesellschaft und Kultur 390. $10-14$.

Razfar, Aria. 2012. Narrating Beliefs: A Language Ideologies Approach to Teacher Beliefs. Anthropology and Education Quarterly 43(1). 61-81.

Reusser, Kurt and Christine Pauli. 2011. Berufsbezogene Überzeugungen von Lehrerinnen und Lehrern. In Ewald Terhart, Hedda Bennewitz and Martin Rothland (eds.), Handbuch der Forschung zum Lehrerberuf, 642-661. Münster: Waxmann Verlag.

Schmidt, Christiane. 2013. Auswertungstechniken für Leitfadeninterviews. In Barbara Friebertshäuser, Antje Langer and Annedore Prengel (eds.), Handbuch Qualitative Forschungsmethoden in der Erziehungswissenschaft, 473-486. 4th ed. Weinheim Basel: Beltz Juventa.

Schulze, Theodor. 2013. Zur Interpretation autobiographischer Texte in der erziehungswissenschaftlichen Biographieforschung. In Barbara Friebertshäuser, Antje Langer and Annedore Prengel (eds.), Handbuch Qualitative Forschungsmethoden in der Erziehungswissenschaft, 413-436. 4th ed. Weinheim Basel: Beltz Juventa.

SCRIPT and EMACS. 2013. PISA 2012 Nationaler Bericht Luxembourg. Luxembourg: Ministerium für Bildung, Kinder und Jugend, SCRIPT (Service de Coordination de la Recherche et de l'Innovation pédagogiques et technologiques).

SCRIPT and LUCET. 2016. PISA 2015 Nationaler Bericht Luxembourg. Luxembourg: Ministerium für Bildung, Kinder und Jugend, SCRIPT (Service de Coordination de la Recherche et de l'Innovation pédagogiques et technologiques).

STATEC. 2017. Etat de la population: Population par sexe et par nationalité au 1er janvier 2017. http://www.statistiques.public.lu/stat/TableViewer/tableView.aspx?Reportld=12853\&IF_L anguage $=$ fra\& Main Theme $=2 \&$ FldrName $=1$.

STATEC. 2018. Affichage de tableau - Population totale, luxembourgeoise et étrangère, de résidence habituelle au Luxembourg selon le sexe 1821-2017. https://statistiques.public.lu/st at $/$ TableViewer/tableView.aspx?Reportld=12856\&IF_Language=fra\&MainTheme $=2 \&$ FldrNa me=1 (6 December, 2018).

Straub, Jürgen. 2002. Personal and Collective Identity: A Conceptual Analysis. Identities: Time, Difference, and Boundaries, 56-76. New York: Berghahn Books.

Terhart, Ewald. 2010. Heterogenität der Schüler - Professionalität der Lehrer: Ansprüche und Wirklichkeiten. In Sieglind Luise Ellger-Rüttgardt and Grit Wachtel (eds.), Pädagogische Professionalität und Behinderung: Herausforderungen aus historischer, nationaler und internationaler Perspektive, 89-104. Stuttgart: W. Kohlhammer.

Vertovec, Steven. 2007. Super-diversity and its implications. Ethnic and Racial Studies 30(6). 1024-1054.Wagner, Jean-Marc. (forthcoming) Profession -Identität -Diversität Diskursive. 
Positionierungen von luxemburgischen Grundschullehrkräften (Doctoral thesis). University of Luxembourg.

Wood, Linda A. and Rolf O. Kroger. 2000. Doing Discourse Analysis: Methods for Studying Action in Talk and Text. Thousand Oaks, Calif: SAGE Publications, Inc.

Woodward, Kathryn. 2002. Identity and difference. London: Sage. 